\title{
On the Exploration of 'The Id' to Apprehend the Motives of the Murders Committed by Raskólnikov in Dostoevsky's Crime and Punishment Novel
}

\author{
Ni Putu Fatmaha Lindawati ${ }^{1}$, I Made Netra ${ }^{2}$ \\ English Department \\ Faculty of Arts-Udayana University \\ Denpasar \\ putu.fatmahalindawati@gmail.com \\ Faculty of Arts -Udayana University \\ Denpasar
}

\begin{abstract}
The objectives of this study are to explore the influence Raskólnikov's Id on his motive murdering Alyona Ivanovna and her sister, Lizaveta; altogether to apprehend his motivations on committing the murders. The data in this study were collected from a novel entitled Crime and Punishment, written by a Russian author, Fyodor Dostoevsky. For collecting the data, this study used observation method and note taking technique; while to analyse the data, it used qualitative method as the data were in the form of texts. The theory used for analysing the data was the psychoanalysis theory proposed by Freud, which focused more on the Id and the concept of instincts. As the result, Raskólnikov's Id was found to have a significant influence on his motives of committing the murders as his instinct persistently tried to up hold his pride as a man while he was crushed by poverty. His main motive on murdering Alyona Ivanovna was to avoid his pride being hurt as he found out that his family was suffering because of him. Meanwhile, his motive on murdering Lizaveta was purely come from his fear of failing to fulfil his first objective.
\end{abstract}

Index Terms - the Id, motives, novel.

\section{INTRODUCTION}

According to McLeod [1], the Id described as a composition of primitive and unsocialized biological urges and drives which is placed deep inside the unconscious mind. It is guided by the pleasure principle; therefore, it always seeks for pleasure and avoids feeling threatened or experiencing any tension. In order to maximize the pleasure it would gain at the moment, it becomes uncaring of the eventual consequences of its impulses. As the Id has no contact with reality, its nature is unchanged; thus, it has no concept about right and wrong. As long as the result makes the Id feels satisfied, then it considered a good output and so if it is the contrary. Therefore, the Id is associated as the pulses of energy which is chaotic in its nature. It contains some instincts that hold the true purpose on every action took by an individual.

Meanwhile, Martin [2] states that motive is a force which affected the behaviours of an individual that can be noticed consciously or unconsciously. As the Id has the goal of every action that being taken, motive holds the purpose of fulfilling the Id's impulses. It can be said that every action has a motive behind it, and a motive contains the impulse of the Id in it. However, because the Id was placed deep inside unconsciousness, its influences on the motives and actions mostly are unnoticed.

Crime and Punishment is a novel written by Dostoevsky [3] that explores the psychology of someone who is suffering in the harsh society or unstable psychological 
states. It tells a story about Rodion Raskólnikov, an intelligent young man who committed an awful crime but did not fully aware of the true nature of his crime. The phenomenon that experienced by Raskólnikov in the story is related to the explanation about 'the Id' and motive as above. Therefore, in order to be able to appreciate this work better, being able to apprehend his motives on the murders he committed is necessary.

Thus, two problems are formulated in this study; what are Raskólnikov's motives on the murders he committed and what does the influence of Raskólnikov's Id has on his motives regarding the murders he committed. With those problems, the aims of this study are to apprehend Raskólnikov's motives on the murders and to explore the influence of his 'Id' on his motives of committing the murders.

This study only focuses on the influence of Raskólnikov 'Id' that showed in the story, as well as his motives of murdering Alyona Ivanovna and her younger sister, Lizaveta. Therefore, the discussion of this study will be limited only on any texts that express the influence of Raskólnikov's Id and his motives of committing the murders.

\section{2. ResEARCH METHOD}

There are some methods used in this study which include the data source; method and technique of collecting data; and method and technique of analyzing data.

The data for this research was taken from a novel entitled Crime and Punishment, written by Dostoyevsky [3]. This novel originally was written in Russian. However, the one used in this study is the English version which translated by Constance Garnett and published by Wordsworth Press as a Wordsworth Limited Edition novel in 2000.

The story was chosen because Dostoevsky has been praised as a writer whose works had a great understanding of psychology. Crime and Punishment itself is the most popular of his great novels. It combines some of alluring psychological issues and fascinating detective story which makes it can be enjoyed as a serious piece of art or an entertaining reading material. Moreover, it was even praised by Freud for its important contributions of implementing psychology in literature.

For collecting the data, this study used the observation method; meanwhile, for the technique, this study used notetaking technique. Here are some steps of collecting the data: firstly, the story was read extensively and repeatedly to get a deeper understanding of the story. Secondly, search for any clauses and sentences which indicate some hints of Raskólnikov's motives on the murders and the influence of Raskólnikov's Id on them. Finally, take note for any texts that contains the clauses and sentences which indicate Raskólnikov's motives on the murders and the influence of his Id on them.

In order to analyse the data, this study used a qualitative method as this is the most appropriate method for conducting social science study involving psychology and literature. The data were in the forms of clauses or sentences in the context of the texts and analysed using psychoanalysis proposed by Freud [4]. This theory then was used to answer the formulated problems and fulfil the aims of the study.

\section{3. ReSEARCh AND DISCUSSION}

Human mind consists of two parts; the conscious and the unconscious. The unconscious is what cannot be reached by the conscious and has the ability to come to the surface as an action that most people are unaware of [5]. Because people mostly face conflicts and tensions daily, human mind then develops the ability to repress these conflicts and tensions deeply under the unconsciousness to avoid any anxiety and distress. Therefore, looking deeper into the unconscious mind is the best way to understand the motive behind any action that taken by an individual.

Rodion Raskólnikov, the main character of Crime and Punishment novel, is an intelligent man that due to some circumstance is crushed by poverty. In this situation, he then sees the only solution for his problem is by killing a certain greedy old woman which is despised by everyone. However, as he performed his plan, the old woman's younger sister suddenly appeared in the crime scene. Thus, he had to kill her too in order to protect himself from being discovered as a murderer.

These murders he had committed then affected his mental stability. However, as the story gets going, Raskólnikov started doubting his true motives on the murders. At first, he thought that he murdered to rob. Therefore, he could help providing for his family and prevent his sister to sacrifice herself by marrying a man she did not love. However, after he murdered and robbed the old woman, he did not even touch the money he had taken from her. Thus, he became confused about his true motives on the murders he had committed.

\section{A. Apprehending the true nature of Raskólnikov's Motives}

Behavior is the result of desires, impulses and memories, which even though have been repressed into unconsciousness, still influence the actions taken by an individual [4]. Thus, because these behaviors are affected mostly by the desires and impulses, every action that was taken by an individual always contains a goal that known as 'motive'.

A motive originally developed from the instinct inside the Id, which is considered as the oldest part of mind system that helps an individual to survive [6]. As it is placed deep inside the unconscious, the Id has no contact at all with reality. Therefore, the Ego was evolved to help to fulfil the impulses of the Id. Through the Ego, the Id puts all his demands to be fulfilled; and as it was born from the Id, the Ego should obediently fulfil its demands. Thus, any action took by an individual always holds a motive to satisfy the 
Id's impulses behind it.

Crime and Punishment is a psychological novel that presents a detective story where the criminal himself was put as the one who try to discover his own motive on the murders he had committed. As he was unsure about his own motives, Raskólnikov was try to apprehend his motives by confessing his crime to someone he had trust. Then, through his confession to Sónia, Raskólnikov tried to confront and plumb the motives of his own crime as her persistence for explanation was kept forcing Raskólnikov to examine his motives and to understand them himself.

Therefore, he widely starts to offer her an array of conflicting reasons; plunder, hunger, bad heart, his Napoleonism, his desire to aid his family and to secure his university career and personal independence. However, Sónia told him that none of them could explain his current unhappiness.

Thus, Raskólnikov once again tried to give her his theory 'that I only kill a louse' (p.351), but she simply rejected it as she told him that she is 'not a louse' but 'human being'. Then, he came with the environmental excuse, saying 'tiny rooms cramp the soul and the mind' (p.351), but he knew it was not strong enough reason, even for himself. He then changed it back into the other theory as he said 'He who despises most things will be a lawgiver' (p.352). But he decided to change it again into pride as he confessed that ' $\mathrm{I}$ wanted to have the daring' (p.352).

In the end, he reprised both his theory and his selflacerating sense of his abject failure by saying that 'I wanted to find out then and quickly: whether I was a louse like everybody else or a man' (p.353).

Unfortunately, all his explanations then fell into a chaotic culminates in the searing of his recognition for his crimes: 'Did I murder the old woman? I murdered myself, not her!' (p.353).

Despite from his confusion on his own motives of murdering Alyona Ivanovna and her sister, Lizaveta, Raskólnikov main motive is just referred to his pride. To rob the old woman, he would like to save his pride from being humiliated as he had crushed by poverty and could not do anything to help his family. To murder the old woman, he was about to prove himself as the part of extraordinary man that would able to transgress the law at will, which also refer to his pride. And to murder Lizaveta, he was about to protect his pride from being discovered as a murderer. Thus, the true nature of his motives on committing the murders is actually concerned on his pride.

\section{B. The Influence of Raskólnikov's "Id"}

The Id is innate since an individual was born and it works with pleasure principle that makes it seeks for satisfaction and avoids feeling threatened or discomforting [1]. It has no concepts of right or wrong as it is chaotic in its nature and it is manifested as desires and impulses that demand to be fulfilled. Therefore, the Id is considered as the one that mostly influences the motives on every action that is taken by an individual.

Since it is placed deep inside the unconscious and has no contact with reality, an individual usually unaware of it as its true nature was modified continuously by the Ego to avoid colliding with the Superego. In this case, Raskólnikov had also experienced a similar situation where he was quite unsure about his own motive on murdering the old pawnbroker, Alyóna Ivanovna and her sister, Lizaveta.

At the beginning of the story, the readers were made to believe that he was simply contemplating the murder because he was in the need of money; he was helplessly broke and had a debt to his landlady. On that point, his Id seemed as it was demanded 'a change in the environment' as he also said that he was hoping for 'a fortune all at once' (p.27) to his housemaid. However, the thought of finding a proper job to provide himself and his family sure had come to him as showed in (3.2-1).

(3.2-1) 'Of course, I've been meaning lately to go to Razumihin's to ask for work, to ask him to get me lessons or something ... Well and what then? What shall I do with the few coppers I earn? That's not what I want now.' (p.47)

In the story, Raskólnikov kept thinking to meet his friend, Razumihin, to ask for a job. However, his Id rejected this solution as it thought that this solution will take some times to change his situation. Thus, he certainly sure that the solution is 'not what he wants' for solving his current problem. This rejection perhaps related to the nature of the Id that keep wanting everything being solved by the fastest solution with the most satisfying result.

As for Raskólnikov, murdering the greedy old pawnbroker is the only solution that would benefit him. He would get a lot of money at once and the glory as an extraordinary man for he believes that there is an honour awaits those who are able to cross the boundary of morality and transgress the law. Unfortunately, after he rehearsed his plan, he started doubting his judgement as he became aware that his physical and psychological condition was not ready for something like murder. Therefore, he started loathing his thoughts as he denied admitting his incompetence.

Raskólnikov almost abandoned his plan after he went for rehearsing the murder, but that was not so long until his mother's letter arrived and became the final force for him to rethink his plan again. When he concerned by the fact that his sister would sacrifice herself for the benefit of their family, and even worst, it was mostly for his benefit, a sudden chance to perform his vicious plan came. After he learnt that the old woman would be alone on a certain day, Raskólnikov decided to take back the idea of murdering the old woman. However, before he committed the murder, a flashback on his true intention was showed.

(3.2-2) 'But I think, if you would not do it yourself, there's no justice about it...' (p.59)

The (3.2-2) was a conversation between Raskólnikov's fellow student and a young officer, which unexpectedly overheard by Raskólnikov after his first meeting with Alyóna Ivanovna. And after that peculiar discussion about 
killing the old woman for 'justice', Raskólnikov himself was said to actually have 'the very same idea' (p.59) with them. This conversation occurred because Alyóna Ivanovna, the old pawnbroker woman had been famous for making people who already suffered, suffer more on their suffering; in conclusion, she had a bad reputation herself that makes anyone could easily dislike her except for her money.

From (3.2-2), it seems like what makes him decided to kill the old woman was based on the justification of this 'justice' that was said to be questioned without bravery. This misleads 'justice' may provide some evidence on his true motive on the murder, but it cannot be simply put as the demand of the Id.

According to Thompson and Mathias [6], the Id only seeks something that could benefit and satisfy an individual's needs or desires and not the others. Therefore, his 'justice' cannot be considered as it was demanded by his Id if it was put as something he would do for the sake of the others. On the other hand, his confession to Sónia then had revealed more on the true nature of this 'justice' he had believed.

(3.2-3) '... I wanted to have the daring ... and I killed her. I only wanted to have the daring, Sónia! That was the whole cause of it!' (p.353)

To Sónia, on (3.2-3), Raskólnikov said that he had decided to commit the murder because of 'the daring'. This may refer to (3.2-2) when he had overheard on the tavern, that some people out there actually have the same idea with him, however, they are too afraid to 'pick up the power'.

Therefore, by achieving what those people cannot achieve, Raskólnikov was hoping for claiming 'the daring' for himself. This 'daring' also may be associated with his pride as he believed that he was a lot better than the other men, for he was able to commit the murder by himself and dare to stoop to pick up the power.

Raskólnikov was quite upset after he knew that he cannot provide financially for his family; instead, he just made them suffer even more on his behalf. This kind of discovery had hurt his pride to a certain extent. Thus, it is natural for him as a man to try to retrieve his pride by using Alyóna's murder as proof that he is an extraordinary man that he always thought. Moreover, with the money he had after robbing the old pawnbroker, he could both save his family from their financial problems and protect his pride as a man.

Moreover, in his confession on (3.2-3), he also stated 'that was the whole cause of it'. Due to his delirious condition after committing the murders, this statement cannot be determined if it came from his consciousness or unconsciousness. By murdering the old woman, Raskólnikov wants 'the glory after transgressing the boundary of morality'.

His Id was demanding for 'praise' and 'acknowledgement', which Raskólnikov perhaps unconsciously aware of this himself, therefore he slipped that statement on (3.2-3). He was trying to tell Sónia that 'his pride' is the real cause of everything; that he killed the woman only to satisfy his Id's impulse for pride. However, even though he had been able to fulfil this objective by murdering the old pawnbroker, the result is not come as what he was expected.

(3.2-4) Fear gained more and more mastery over him, especially after this second, quite unexpected murder ... The feeling of loathing especially surged up within him and grew stronger every minute. (p.71)

On (3.2-4), Raskólnikov was said to feel his fear rising after the unexpected murder of Lizavéta. Since in the beginning, Raskólnikov had only planned to murder the greedy old pawnbroker, but the sudden appearance of her younger sister, Lizavéta, on the crime scene has violated his main objectives to fulfil his Id's demand, to murder without a witness. Lizavéta's arrival had made him take an impulsive action to cover this miscalculation on his plan. To kill Lizavéta, it saved him from being discovered by anyone, but it also violated his objectives to murder without being seen or discovered.

By murdering Lizavéta, who had seen his face and murdering her sister, Raskólnikov tried to eliminate his fear of being discovered on the murder he had committed. However, he lacks reasons in murdering her as she is innocent and her death only proved the flaws in his plan. His Id only demands to eliminate any witness, and his Ego has no strong reason to protect this action from the judgment of morality. Therefore, he starts to feel 'the fear' and 'loathsome' for what he had done.

(3.2-5) 'He ... did not mean to kill that Lizavéta... he ... killed her accidentally.... He meant to kill the old woman when she was alone and he went there ... and then Lizavéta came in ... he killed her too.' (p.345)

On his first confession to Sónia in (3.2-5), Raskólnikov did not admit that he was the one who killed Lizavéta who was close to Sónia when she was still alive. Instead, he told her that he was 'the murderer's close friend' and he was 'accidentally kill her' when he intended to kill the old woman. However, this was not held any longer as he finally came out as the murder, but only to admit that he was the one who killed the old pawnbroker. There are two possibilities for this situation; firstly, he probably expects for Sónia to understand this without he even mentioning it again, or secondly, his Id probably would still not accept the truth that he was actually the one who killed her. Either of these possibilities is proved by the word 'accidentally', which is rhetorically related to the next confession and also could be presented as a denial statement. Still, the unexpected murder of Lizavéta has become the failure in fulfilling his Id's demands.

Raskólnikov's Id may seem had changed his demands along the story; since it was cover up by a lot of excuses that created by his Ego to avoid clashing with the judgement of the Superego. Still, look deeper on the nature of his Id, there is only one thing that he desired since the beginning of the story, pride. The pride of being able to change the situations by his own hand after transgressing the law and morality; it has manifested into an idea of murdering a greedy old woman for what he believed as 'justice'. As for Lizavéta's case, her murder was the impulsive action that he 
should do to protect his pride from being caught as a criminal. Thus, the pride that desired by his Id is what motivated him to murder the old woman and her younger sister.

\section{Conclusion}

As an intelligent man, Raskólnikov has a high pride. This is shown on his theory of 'the extraordinary man' and on his excitement about his 'idea of being a lawgiver' for society. Thus, he sees the idea of murdering the old woman as 'an act of justice' that only he was dare to take step on it. However, he also ended up killing the old woman's sister who is innocent. This murder then reveals the nature of Raskólnikov's motives on murdering the old woman and her sister, which is influenced by his pride that created unconsciously by his Id.

\section{REFERENCES}

[1] McLeod, S. 2016. Id, Ego, and Superego. Retrieved from www.simply psychology.org/psyche.html

[2] Martin, C. 2011. Motives and Drives in Psychology. Student Publication. 481.

[3] Dostoevsky, F. 1866, 2000. Crime and Punishment. Translated into English by Constance Garnett. Wordsworth Press: Wordsworth Classic Limited Edition.

[4] Freud, S. 1923. The Ego and Id. Trans: Joan Rivera, London: Hogarth and the Institute of Psychoanalysis.

[5] Goodale, M. A. \& Milner, D. A. 1992. Separate Visual Pathways for Perception and Action. University of St. Andrews, United Kingdom.

[6] Thompson, T. \& Mathias, P. 1994. Lytle's Mental Health \& Disorder: Second Edition. Bailliére Tindall: London. 